Article

\title{
Soil Carbon Storage and Its Determinants in Forest Fragments of Differentiated Patch Size
}

\author{
Chunyu Shen ${ }^{1,2}$, Lei Ma ${ }^{3}$, Jiaxi Hu ${ }^{1,2}$, Liyang Huang ${ }^{1,2}$, Yujuan Chen ${ }^{1,2}$ \\ and Dongsheng Guan 1,2,* \\ 1 School of Environmental Science and Engineering of Sun Yat-sen University, No. 135, Xingang Xi Road, \\ Guangzhou 510275, China; shencym@126.com (C.S.); hujx9@mail2.sysu.edu.cn (J.H.); \\ huangly48@mail2.sysu.edu.cn (L.H.); chenyuj@mail.sysu.edu.cn (Y.C.) \\ 2 Guangdong Provincial Key Laboratory of Environmental Pollution Control and Remediation Technology, \\ Sun Yat-sen University, No. 135, Xingang Xi Road, Guangzhou 510275, China \\ 3 Key Laboratory of Geospatial Technology for the Middle and Lower Yellow River \\ Regions (Henan University), Ministry of Education, Kaifeng 475004, China; qdmalei@sina.com \\ * Correspondence: sysugds@163.com
}

Received: 17 September 2019; Accepted: 15 November 2019; Published: 18 November 2019

\begin{abstract}
Research Highlights: Soil carbon storage (SOC) decreased due to forest fragmentation through lower proportion of macroaggregate distribution, higher storage of fine roots and litter falls, and lower fine root production rate. Background and Objectives: Globally, forest fragmentation processes lead to enormous losses of SOC in forests. We investigated SOC and its determinants in forest fragments experiencing edge disturbances in south China. Materials and Methods: Soil aggregate characteristics, dynamics of fine roots, and litter fall were studied from forest edges to interiors. Generalized linear mixed models were used to model the contributions of fine root and litter fall dynamics to carbon concentration in aggregates. Results: Large and small macroaggregates had higher proportion of aggregate distribution and contributed more carbon to SOC in all types of plots in the present study. SOC significantly increased from forest edges to interiors due to carbon concentration of these two aggregate types increasing from edges to interiors, while the proportion of different aggregate distributions was similar within each plot. The same trend was found with increasing forest patch size. Fine root biomass storage had the strongest impact on carbon concentration in large macroaggregates and microaggregates, with higher fine root biomass storage associated with lower carbon concentration. In addition, biomass storage and production rates of both fine roots and litter falls decreased from forest interiors to edges. Our results showed that SOC was significantly decreased due to the lower proportion of large and small macroaggregate distribution, and lower fine root production rate in forest fragments. Conclusions: SOC loss due to effects of forest fragmentation and forest edges occurred through decreased concentrations of soil aggregates and fine root production rates. Results from this study will enhance our ability to evaluate soil aggregate, fine root, and leaf litter fall contributions to $\mathrm{SOC}$ within forest fragments, and to suggest basic recommendations for the management and conservation of these forest fragments.
\end{abstract}

Keywords: soil aggregates; carbon concentrations; edge effects; litter falls; fine roots

\section{Introduction}

Soil stores the largest reserve of organic carbon in terrestrial ecosystems [1]. In studies of soil organic matter, physical separation of soil into aggregate and particle-size fractions has received increased attention because it enables separation into pools of differing compositions and biological functions [2]. Soil aggregates are the basic units of soil structure and consist of primary particles 
and binding agents. They contain about $90 \%$ of the soil organic matter in the soil surface layers [2]. Aggregates play an important role in soil structure stability, soil organic carbon protection, and nutrient availability, as well as differential microbial activity. Aggregate formation is a key process of soil development, which promotes carbon stabilization by hindering decomposition of particulate organic matter and its interactions with mineral particles [3]. Since physical protection of soil organic carbon within stable soil aggregates is considered to be one of the major soil organic carbon stabilization mechanisms, the effect of land management on aggregate stability in croplands is accepted as a key factor in determining soil organic carbon levels. Many studies have evaluated how soil aggregates respond to micro-environmental conditions [4]. However, much less is known about aggregate formation in fragmented forest soils.

Forests are frequently disturbed by human activities, including urban and agricultural development, deforestation, and road construction [5,6]. As forests become fragmented, the remnant forest patches have different sizes, ages, and degrees of isolation, each of which changes biological communities and the functional attributes of species across taxa [7]. Habitat fragmentation can strongly influence biodiversity and ecosystem services. Forest fragmentation results in the gradual succession of aboveground vegetation and consequently a change in litter fall quantity and quality, root biomass, and soil properties. These, in turn, lead to changes of carbon in the soil organic fractions.

In rural areas of southern China, there are many semi-natural fragments of typical subtropical evergreen broadleaved forests. These fragments are usually well-protected and left undisturbed for religion reasons [8]. Local people generally referred to them as Fengshui forests. Fengshui forests are typical fragment forests widely distributed in southern China.

Anthropogenic forest fragmentation has resulted in new forest edge formation [9]. Forest edges have different microclimates compared to those of forest interiors. Edges often have more light and wind, and are warmer and drier than forest interiors $[10,11]$. The microclimate of fragments could affect the production and decomposition of organic matter, resulting in losses or gains of carbon stocks [12]. The scale and intensity of edge effects depends on vegetation type, edge structure, and edge orientation [13]. In addition, edge effects at a given site within a forest patch depend on the distance from edge, and on the area of forest patch [14,15]. Laurance [16] showed that edge effects are a main reason for the tree mortality, particularly for large trees. This could further influence carbon stock, as wind turbulence and physiological stresses kill trees at forest edges. Barros [12] calculated that SOC (soil carbon storage) increased in Amazonian forest fragments due to tree mortality. Indeed, most of our knowledge about edge effects on carbon accumulation and loss in fragments comes from the Amazonian tropical forests [17], and we lack empirical evidence from other types of forests. Ma [18] studied carbon storage in sub-tropical forest fragments and found that carbon density of forest fragments was significantly influenced by patch size and edge effects. Other studies showed that fragments can be responsible for $9 \%$ to $24 \%$ of the annual global carbon loss [14]. There remains, however, a lack of information on the buildup and breakdown of carbon fractions and soil aggregation in forest fragments.

During recent decades, recognition of the importance of soil carbon sequestration has encouraged the study of the mechanisms involved in the maintenance of soil carbon within soil aggregates [19]. Several researchers have reported the relationship between soil aggregate size and soil carbon concentrations [20-22]. Aggregate formation is one of the main soil-forming processes, distinguishing soil from the parent materials. Plant litter, microorganisms, and soil minerals assemble into soil aggregates. Plant residues and root exudates are assumed to be the main drivers of aggregation in most models of soil structure development. In addition, carbon in soils is affected by the balance between carbon input from vegetation and carbon losses by decomposition [17,23]. Carbon inputs come mainly from leaf and root litter [24]. Fine roots ( $<2 \mathrm{~mm}$ in diameter) are important sources of carbon in litter inputs within forest soils because of their rapid turnover rates [25]. Fine root biomass and structure significantly influence soil carbon cycling rates [26,27]. Plant litter is also an important carbon input to soil [28]. Litter decomposition rate is related to many parameters in numerous studies [29], which lead to different organic carbon decomposition patterns, and therefore 
different SOC sequestration capacity [30,31]. The sequestration potential of carbon in soils is regulated by the chemical composition of plant litter. Litter indirectly moves atmospheric carbon to soils through the physiology of soil heterotrophs that control litter degradation and the formation of soil organic matter through the breakdown and re-synthesis of plant inputs, and by the soil mineral matrix, which stabilizes soil organic matter through physicochemical associations [29]. However, the rate of litter decomposition and incorporation into soil organic matter does not equate the stabilization and turnover rate of litter-derived carbon in the soil. How soil aggregates and SOC are affected by dynamics of fine roots and litter falls in human-modified habitats is still not well understood. Study of the response of SOC in soil aggregates of different lability and sensitivity to root and litter dynamics is needed.

For a better understanding of the underlying mechanisms of carbon uptake and loss in soil due to forest fragmentation, we investigated SOC, soil aggregate distributions, and dynamics of fine roots and litter in forest fragments in south China. We hypothesized that (1) SOC, characteristics of soil aggregates, dynamics of fine roots, and litter falls would be affected by forest fragmentation; and (2) contributions of fine roots and litter to aggregate-associated SOC differed. Results of this study will increase our understanding of process of forest fragmentation and will also contribute to global research on soil carbon loss due to forest fragmentation.

\section{Materials and Methods}

This study was conducted in Guangzhou city, southern China. Guangzhou is located at $22^{\circ} 26^{\prime}-23^{\circ} 56^{\prime} \mathrm{N}$ and $112^{\circ} 57^{\prime}-114^{\circ} 03^{\prime} \mathrm{E}$. The capital of Guangdong province, Guangzhou, has an area of $7434 \mathrm{~km}^{2}$ and a human population of over 13.08 million people. The prevailing climate is sub-tropical monsoon climate and the annual mean temperature is $21.8^{\circ} \mathrm{C}$. Rainfall mainly occurs between April and September with a mean annual precipitation of $1600 \mathrm{~mm}$. This region was originally covered by tropical and sub-tropical species [32].

A total of nine forest fragments of three different patch sizes were selected in the present study: large forest (LF, $\sim 35 \mathrm{ha}$ ), medium forest (MF, $\sim 15 \mathrm{ha}$ ) and small forest (SF, $\sim 5 \mathrm{ha}$ ) patches, each replicated three times. We choose fragments for sampling according to the following criteria: (1) relatively well protected and with low human disturbance, and (2) within the same altitudinal range and with similar climatic conditions. Three $20 \times 20 \mathrm{~m}$ plots were established in each large forest fragment $(\mathrm{LF})$. "Interior plots" (IP) were in the core areas of the large fragments; "Edge plots" (EP) were near the edges of the large fragments; and "Middle plots" were between the former two plots. Only one $20 \times 20 \mathrm{~m}$ plot was established in the core area of each medium (MF) and small (SF) forest fragment. In total, there were total 15 plots in these nine forest fragments.

After removing surface litter, three soil sample blocks of $30 \times 30 \mathrm{~cm}$ width at $0-10 \mathrm{~cm}$ depth were collected at random locations within each sample plot. Soil and fine roots were separated during initial sampling and processed independently. Soil samples were placed in hard plastic boxes and then transported to the laboratory. The soil samples (100 g each) for aggregate separation were air-dried at room temperature (depending on the sample moisture content and on weather conditions) and sieved through the 2000 and $250 \mu \mathrm{m}$ meshes on the Vibratory Sieve Shaker AS 200 (Retsch, Wuppertal, Germany) for $5 \mathrm{~min}$ at an amplitude of $1.5 \mathrm{~mm}$. Large macroaggregates $(>2000 \mu \mathrm{m})$, small macroaggregates $(250-2000 \mu \mathrm{m})$, and microaggregates $(<250 \mu \mathrm{m})$ were collected. Dry sieving was used instead of wet sieving in order to minimize the disruption of aggregates, to avoid redistribution of fine organic particles from large and small aggregates to microaggregates, and to prevent the leaching of dissolved organic matter to the microaggregate size class. All aggregate fractions were crushed and passed through a $177 \mu \mathrm{m}$ mesh sieve, then weighed and fed into a Vario C/N elemental analyzer (Elementar, Hanau, Germany; Daniel et al., 2001). We determined the carbon content (total C) in different size soil aggregates. 
The biomass of fine roots was obtained from the above three soil sample blocks within each sample plot. The fine root production rate was determined using the ingrowth core method [33]. In January 2018, 12 root-free mesh bags were systematically placed into the soil within each study plot. Mesh bags were filled with homogenous sieved mineral soil and placed at a depth $10 \mathrm{~cm}$ in the mineral soil. An oven-dried humus clod was placed on top of the mesh bag. The mesh size of the bag material was $5.5 \mathrm{~mm}$. Three samples were collected every three months. A total of 180 ingrowth core samples were collected during the growing seasons. Fine root decomposition rate was determined using decomposition bags. Fine root samples were randomly collected in the study area. Then, they were put into $10 \times 10 \mathrm{~cm}$ nylon bags with $1 \mathrm{~mm}$ mesh openings after cleaning and air drying. Twelve polyester-net fine roots bags with $1 \mathrm{~g}$ dry litter were buried at $10 \mathrm{~cm}$ depth within each sampling plot. Three bags were collected every three months. After collecting bags, all fine root samples were transported to the laboratory and stored in a freezer to ensure minimal damage to the live tissue and minimal change in ion concentrations. At the lab, fine roots were thawed, cleaned, and oven dried at $70{ }^{\circ} \mathrm{C}$ to constant weight for dry biomass [34].

All leaf litter was collected in three $1 \times 1 \mathrm{~m}$ subplots, which were established and surrounded by nets for in each sample plot $(20 \times 20 \mathrm{~m})$. Litter was collected every three months. The litter decomposition rate was determined using decomposition bags. Litter samples were collected randomly within the study area. Twelve polyester-net litter bags $(10 \times 10 \mathrm{~cm} ; 1 \mathrm{~mm}$ mesh) with $3 \mathrm{~g}$ dry litter were buried at $10 \mathrm{~cm}$ depth in each sampling plot. Three bags were collected every three months. Litter was placed into bags, and transported to the laboratory. Litter aliquots from each bag were dried at $70{ }^{\circ} \mathrm{C}$ to constant mass and weighed for calculation of mass loss.

Statistical analyses were performed using R 3.5.2 software [35]. The effect of forest fragmentation on aggregate composition, the distribution of SOC, and carbon concentration in aggregate size classes were tested by ANOVA followed by the Tukey HSD (Honest Significant Difference) post-hoc test (significance level $p<0.05$ ). All data are presented as mean of three replicates \pm standard error. The normality of data was tested for all variables with the Kolmogorov-Smirnov test. When necessary, data were log-transformed to meet the assumption of normality. Linear or nonlinear regression analysis were conducted to test for a relationship between aggregate proportion and carbon concentration in soil. Generalized linear mixed models (GLMM; using the "lme4" package) were used to model the contributions of fine root dynamics and litter fall to carbon concentration in aggregates. For all the explanatory variables, values were standardized by subtracting the mean value of the variables and dividing by the standard deviation. This allows for a direct comparison of the relative importance of these explanatory variables. In addition, plot ID was included as a random effect in these analyses.

\section{Results}

\subsection{Characteristics of Three Sizes of Soil Aggregates within Forest Fragments}

- The proportion of large and small macroaggregates differed among plot types.

- Microaggregates made up less than $10 \%$ of all aggregates, which was significantly lower $(p<0.05)$ than the proportions accounted for by small macroaggregates and large macroaggregates in all plots (Figure 1).

- The proportion of aggregates that were microaggregates increased while the proportion that were large macroaggregates decreased from edges to interior at 0-10 $\mathrm{cm}$ depth (Figure 1).

- The proportion of aggregates at the surface layer that were microaggregates decreased slightly as the patch size decreased. 

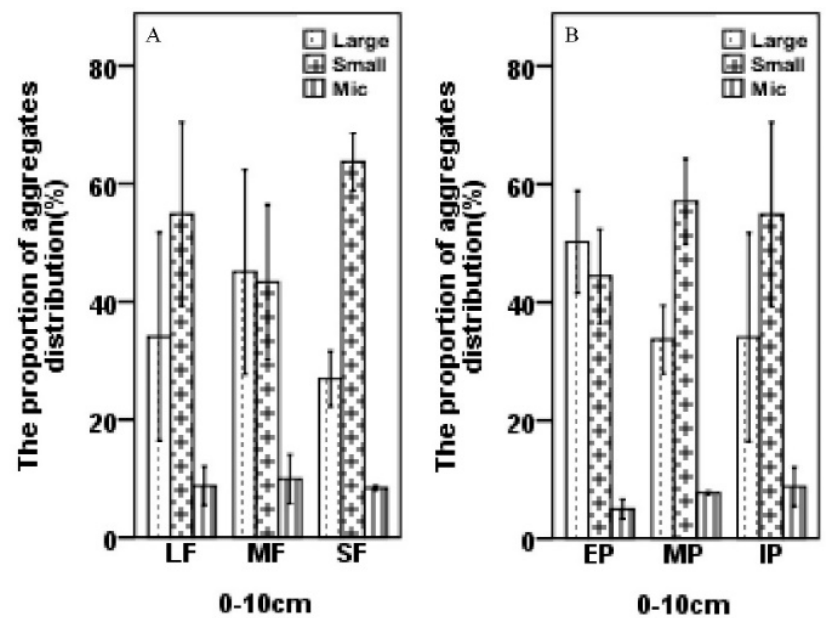

Figure 1. The proportion of all soil aggregates accounted for by three type of soil aggregates among different type of plots: (A) proportion of three types of aggregates among different forest fragments with different patch sizes; (B) proportion of three types of aggregates from forest edges to interiors. LF: large forest; MF: medium forest; SF: small forest; EP: edge plots; MP: middle plots; IP: interior plots.

\subsection{Carbon Concentrations and Stocks in Soils}

- Soil carbon concentration of all aggregates was in the order LF $>$ MF $>$ SF at 0-10 cm depth (Figure 2). Soil carbon concentrations of large macroaggregates $(20.33 \mathrm{~g} / \mathrm{kg})$, small macroaggregates $(18 \mathrm{~g} / \mathrm{kg})$, and microaggregates $(16.13 \mathrm{~g} / \mathrm{kg})$ in SF were significantly $(p<0.05)$ lower than those in $\mathrm{LF}(58.6 \mathrm{~g} / \mathrm{kg}, 58.27 \mathrm{~g} / \mathrm{kg}, 62.33 \mathrm{~g} / \mathrm{kg}$, respectively) at the surface layer.

- The carbon concentration of aggregates was not different between size classes within plots (Figure 2).

- The concentration of carbon in soils significantly increased as patch size increased and from forest edges to interiors in LF (Figure 3). The carbon concentrations increased from $18.07 \mathrm{~g} / \mathrm{kg}$ to 57.3 $\mathrm{g} / \mathrm{kg}$ in soils comparing SF to LF and from $33.97 \mathrm{~g} / \mathrm{kg}$ to $57.07 \mathrm{~g} / \mathrm{kg}$ from forest edges to interiors (Figure 3).

- Carbon concentration was significantly higher in LF than in SF, and higher in IP than in EP, respectively. The similarly trends were found in SOC of different type of plots (Figure 4).
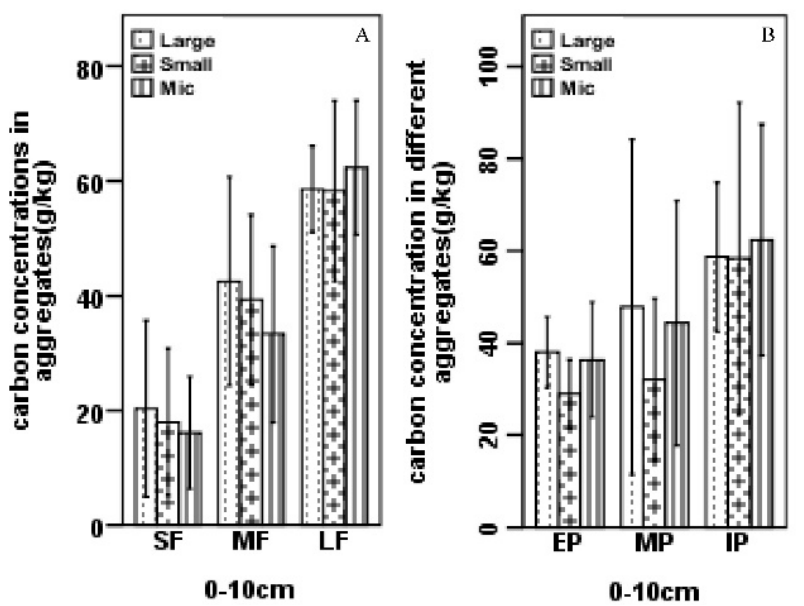

Figure 2. Soil carbon concentration in aggregates $(\mathrm{g} / \mathrm{kg})$ among different type of plots: (A) soil carbon concentration in aggregates $(\mathrm{g} / \mathrm{kg})$ among different forest fragments with different patch sizes; (B) soil carbon concentration in aggregates $(\mathrm{g} / \mathrm{kg})$ from forest edges to interiors. 


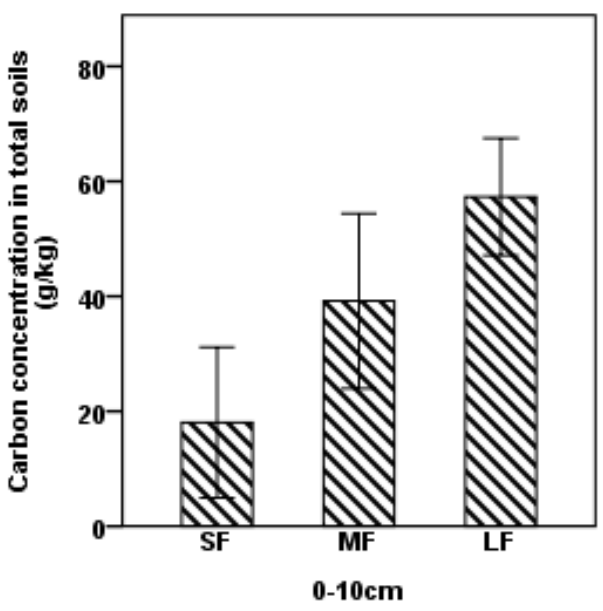

(A)

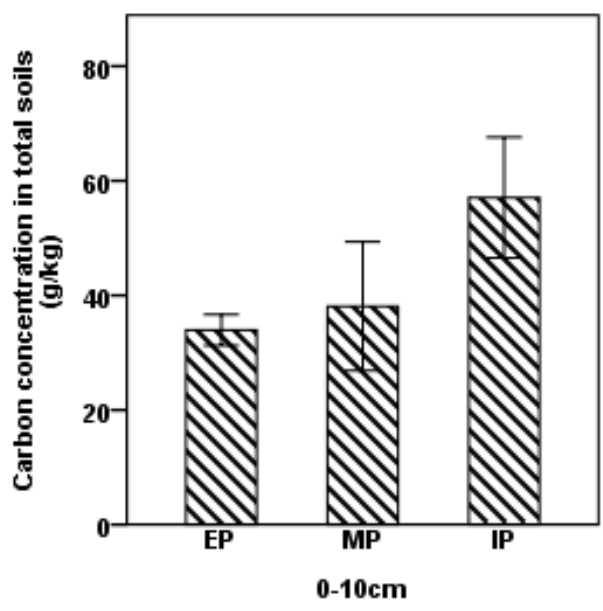

(B)

Figure 3. Soil carbon concentration in soils $(\mathrm{g} / \mathrm{kg}$ ) among different type of plots: (A) soil carbon concentration in soils $(\mathrm{g} / \mathrm{kg})$ among different forest fragments with different patch size; (B) soil carbon concentration in soils $(\mathrm{g} / \mathrm{kg})$ from forest edges to interiors.

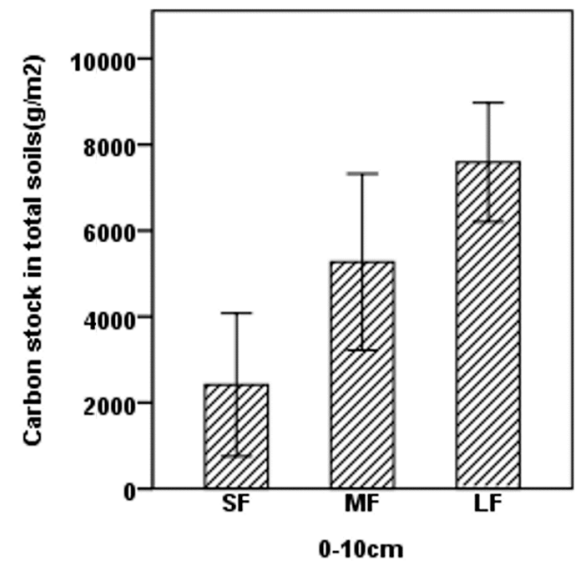

(A)

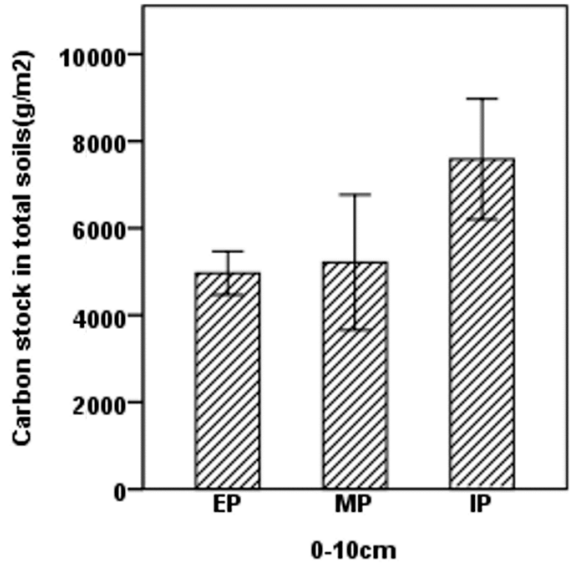

(B)

Figure 4. SOC (soil carbon storage) in soils among different type of plots: (A) SOC in soils among different forest fragments with different patch size; (B) SOC in soils from forest edges to interiors.

\subsection{Dynamics of Fine Roots and Litter Fall}

- Fine root biomass storage was $1.62 \mathrm{Mg} / \mathrm{ha}$ in LF, which was significantly greater than that in MF (1.48 Mg/ha). Fine root production rate was $2.18,1.43$, and $1.06 \mathrm{Mg} / \mathrm{ha} \cdot \mathrm{y}$ in LF, MF, and SF, respectively, during the study period (one year; Table 1 ). 
Table 1. Biomass (Mg/ha), production $(\mathrm{Mg} / \mathrm{ha} \cdot \mathrm{y})$, and decomposition rates (\%/y) of fine roots and litter fall among different forest patches.

\begin{tabular}{cccc}
\hline & Large Forest & Medium Forest & Small Forest \\
\hline Fine root biomass storage & $1.62 \pm 0.53$ & $1.48 \pm 0.24$ & $1.60 \pm 0.30$ \\
Fine root production rate & $2.18 \pm 0.42$ & $1.43 \pm 0.52$ & $1.06 \pm 0.30$ \\
Fine root decomposition rate & $42.13 \pm 4.02$ & $56.37 \pm 1.38$ & $48.49 \pm 6.26$ \\
Litter falls biomass storage & $508 \pm 52.66$ & $433 \pm 42.85$ & $327 \pm 35.31$ \\
Litter falls production rate & $640 \pm 14.24$ & $555 \pm 24.82$ & $444 \pm 42.37$ \\
Litter falls decomposition rate & $45.09 \pm 7.38$ & $31.40 \pm 1.12$ & $51.32 \pm 12.13$ \\
\hline
\end{tabular}

- Fine root biomass storage and production rate decreased from LF to SF and from forest interiors to forest edges. However, decomposition rate increased from forest interiors to edges (Table 2). Similar trends were found in the dynamics of litter fall.

Table 2. Biomass (Mg/ha), production (Mg/ha. $\mathrm{y})$, and decomposition (\%/y) of fine roots and litter falls within plots from forest interiors to edges.

\begin{tabular}{cccc}
\hline & Inner Plots & Middle Plots & Edge Plots \\
\hline Fine root biomass storage & $1.62 \pm 0.53$ & $1.14 \pm 0.45$ & $0.88 \pm 0.18$ \\
Fine root production rate & $2.18 \pm 0.42$ & $1.47 \pm 0.39$ & $1.03 \pm 0.11$ \\
Fine root decomposition rate & $42.13 \pm 4.02$ & $45.25 \pm 7.07$ & $49.16 \pm 6.11$ \\
Litter falls biomass storage & $508 \pm 52.66$ & $426 \pm 63.69$ & $301 \pm 75.76$ \\
Litter falls production rate & $640 \pm 14.24$ & $526 \pm 11.55$ & $490 \pm 28.67$ \\
Litter falls decomposition rate & $45.09 \pm 7.38$ & $50.05 \pm 11.16$ & $55.24 \pm 3.44$ \\
\hline
\end{tabular}

\subsection{Contributions of Dynamics of Fine Roots and Litter Fall to Aggregate Carbon Concentration}

- Fine root storage had the strongest impact on carbon concentration in large macroaggregates and microaggregates, with higher fine root biomass storage having a decreased carbon concentration. However, fine root decomposition rate had positive effects on carbon content in large macroaggregates (Table 3).

- For small macroaggregates, fine root production and decomposition rate had significantly positive effects, while fine root biomass storage, litter fall biomass storage, and litter fall decomposition had significantly negative effects on carbon concentration.

- In addition, fine root production rate had significantly positive effects on carbon concentrations of microaggregates. Generally, contributions of fine root dynamics to carbon concentration of these three aggregates were higher than litter fall dynamics.

Table 3. Summary of generalized linear mixed models analyses of aggregates carbon concentration.

\begin{tabular}{|c|c|c|c|c|c|c|}
\hline Variables & LA & & SA & & MA & \\
\hline Fine root biomass storage & -0.61 & $* * *$ & -0.37 & $* * *$ & -0.51 & $* * *$ \\
\hline Fine root production rate & 0.67 & & 1.6 & $* * *$ & 1.3 & *** \\
\hline Fine root decomposition rate & 0.02 & $* *$ & 0.23 & $* * *$ & 0.09 & \\
\hline Litter falls biomass storage & 0.39 & & -0.56 & $* * *$ & -0.24 & $* * *$ \\
\hline Litter falls production rate & 0.11 & & 0.08 & & 0.11 & \\
\hline Litter falls decomposition rate & -0.02 & & -0.14 & $* * *$ & -0.02 & \\
\hline
\end{tabular}

LA, large macroaggregate; SA, small macroaggregate; MA, microaggregate. $0.1>p>0.05 ;{ }^{* *} 0.01>p>0.001$; *** $p \leq 0.001$. 


\section{Discussion}

Forest fragmentation processes can affect soil aggregation, including aggregate formation by biogenic and physicogenic processes. In the present study, soil aggregate size distribution was dominated by the macroaggregate fraction (including large and small macroaggregates) in all types of plots. Our results agreed with the findings of $\mathrm{Li}[36]$ who observed that macroaggregates $>2 \mathrm{~mm}$ in size in tea plantations accounted for $70-80 \%$ of all aggregates. Some studies focused on the common factors that influenced aggregate distribution, such as tillage and agricultural management practices $[21,37,38]$. Six [39] suggested that macroaggregates are more stable in highly weathered tropical or sub-tropical soils because oxides are the dominant binding agent in oxide-rich soils. In addition, our results showed that the representation of microaggregates increased from forest edges to interiors. This tendency may be partly due to more roots mechanically breaking up existing aggregates [40]. Ma [11] reported that the biomass of fine roots was significantly greater in inner versus edge plots. Additionally, a moist soil environment in the core areas of fragments favored the presence of earthworms [41]. Many studies indicated that earthworms have a direct and fast impact on microaggregate formation [42]. Overall, forest edges had obvious impacts on aggregate distribution in the present study.

The link between SOC conservation and the size of aggregate particles has been found [43]. A number of studies have focused on the relationships between aggregate size classes and aggregate-associated carbon concentration. Different aggregate size fractions have different soil organic matter concentrations and turnover times according to former studies [21,44]. However, our results showed that soil carbon concentrations among different size aggregates were not significantly different among different plot types (Figure 2). There were significant differences between carbon concentration of all type of aggregates from forest interiors to edges. Previous studies on temperate soils indicated that organic matter was the main driver of soil aggregation and binding materials [45]. Conversely, LiuSui [44] reported a less influential role of organic matter in aggregation processes. Hontoria [21] suggested that generalization to other tropical soils should be done with care because oxisols have substantial contents of clay and oxy-hydroxides in the surface layer. Similarly, soils in the present study experienced a typical sub-tropical climate, and sub-tropical soil can be considered as a tropical soil for the dominance content [21]. Macroaggregate dynamics control physical soil carbon stabilization, as microaggregates formed within macroaggregates are the structures in which soil carbon is preferentially stabilized in both temperate and tropical soils [46]. Our results were consistent with the findings of Six [39] that there are only small differences or no difference between aggregate-associated organic carbon concentrations in tropical soils.

Our results showed that the accumulation of carbon in soils was mainly due to carbon concentration in aggregates rather than the distribution of aggregate size classes in each plot. Contributions of fine root dynamics to carbon concentration of soil aggregates were greater than that of litter fall dynamics. These parameters differed significantly among plots, and in agreement with our expectations, differences were related to surface soil aggregates. In addition, fine roots and litter fall decomposition are a key process in nutrient, mass, and energy dynamics of forest ecosystems, which contribute $25-80 \%$ to the total SOC annually according to former studies [12,37]. In the present study, the highest fine root and litter fall decomposition rates were found near forest edges, which contribute significantly to soil organic matter pools. However, increased decomposition rate of fine roots and litter in forest edges was contrary to our expectations. Microclimatic changes after forest fragmentation, such as increased temperature, increased wind speed, and decreased soil moisture [14,47], are affecting SOC in a different way because these factors are directly related to changing fine roots and litter fall decomposition rates as suggested by former studies [12] and our results (Table 2). Soil organic matter from fine roots and litter fall could be quickly decomposed as a function of temperature increases in the forest edges, leading to a reduction of SOC in these areas.

In forest ecosystems, litter decomposition is a complex process resulting from the interaction of abiotic and biotic drivers, such as temperature, moisture, and community characteristics [48]. Complex molecules are presumed to be preferentially stabilized as SOC based on the generally 
accepted concept that the chemical composition of litter is a major factor in its rate of decomposition. Hence, a direct link between litter dynamics and soil carbon quantity has been assumed and accepted in soil carbon models. Here, however, we present data from a field experiment that illustrates the influence of litter dynamics on the quantity of soil carbon. The conceptual model of soil aggregate turnover by Six [40] described the decomposition of litter into more soil carbon compounds as they are incorporated into aggregates and organomineral complexes. Relatively fresh litter fall can contribute to aggregate formation via soluble, leachable organic compounds that function as an aggregate binding agent of roots, and associated mycorrhizae and rhizodeposits are presumably the principle sources of fresh organic matter facilitating macroaggregate formation [4]. The associated slower rate of litter decomposition, which generally lags behind the rate of litter input, results in the accumulation of plant heteropolymers in soils. Moreover, most residues that remain at the final stages of the decomposition of recalcitrant litter are incorporated into soils through a physical transfer pathway, thus further increasing soil carbon in such ecosystems [30]. Fragmentation always lead to microclimatic changes, and compared to the forest interiors, edges had higher temperatures, more wind, and greater availability of resources, such as light and nutrients [49]. Microbial activity can be stimulated by higher temperatures, promoting a faster decomposition of organic matter [50]. Further, litter species richness, and especially litter of certain species, may influence decomposition by modifying fungal community composition in both foliar and root litter [51]. The formation of SOC is controlled more by the litter quantity and its interaction with the soil matrix than by litter decomposition rate. Thus, although litter dynamics affect short-term dynamics of carbon decomposition and accumulation in the soil, longer-term SOC patterns cannot be predicted based on these short-term litter dynamics effects on carbon transfer rates. Therefore, the effects of litter fall dynamics on aggregates appear to be limited to the short term and do not significantly affect the physical stabilization of soil carbon, according to previous study [46]. Because the process of soil carbon stabilization in aggregates is related to microbial degradation of litter inputs, our findings may not apply in environments where photodegradation is a dominant form of litter decay.

Fine root and litter fall biomass, production, and decomposition rates were within the range reported from other sub-tropical forests [32]. It is well known that fine roots perform a variety of functions: they link every component of the forest ecosystem, have strong relevance for inorganic matter assimilation, function as a major source of organic matter in the soil, and last but not least, are responsible for water and nutrient uptake [52]. Previous study [53] found that the rate of SOC sequestration and the quality of SOC depend on the complex interaction between fine roots, climate, soils, and tree species. Overall, SOC is affected by the balance between carbon input from vegetation and carbon losses by decomposition [23,24]. Previous studies indicated that roots are a large source of light fraction material in forest soils [4]. Fine root biomass has been found to vary in relation to forest stand characteristics, such as tree species, stand age, density, basal area, and soil properties, or environmental factors, chiefly air temperature, amount of precipitation, geographical location, and elevation [54]. Sun et al. [55] showed positive effects of tree species richness on the evenness of vertical distribution of fine roots and, as a consequence, on fine root biomass. Finer [56] suggested that fine root biomass increases with tree species diversity in pure broadleaf forests. Species diversity explained $7 \%$ of the variation in tree fine root biomass in broadleaf stands [57,58]. Ma [11] showed that tree density and species richness were significantly greater in forest interiors than near forest edges. These may well explain the biomass production rate of fine roots and litter falls in core areas of these patches.

Our study revealed important variations of SOC between different types of plots within forest fragments in south China. Soil carbon-flow balance is positive in forest fragments, suggesting that carbon inputs derived from decomposition of fine roots and litter fall to mineral soil outweigh the losses from microbial respiration. Distance to the edge appears to have an indirect influence on this result due to microclimatic changes, leading to the decrease in soil carbon storage at forest edges. Long-term monitoring of permanent plots will be needed to track the impacts of future climate change. 


\section{Conclusions}

We analyzed SOC and its determinants in forest fragments of differing patch sizes in south China. We found that SOC was significantly affected by forest fragmentation and edge effects. Higher SOC in both forest interiors and larger size fragments resulted from higher carbon concentration in all type of aggregates, but especially in large and small macroaggregates. In addition, fine root biomass and decomposition rate had negative and positive effects on carbon concentration in macroaggregates, respectively. Litter fall biomass and decomposition rate had negative effects on carbon concentration in small macroaggregates. In conclusion, SOC decreased due to forest fragmentation through a reduction in the proportion of all aggregates accounted for by macroaggregates, higher storage of fine roots and litter, and lower fine root decomposition rate. Our results would greatly improve understanding of soil degradation in fragmented forests due to habitat fragmentation.

Author Contributions: Conceptualization, C.S.; methodology, C.S.; software, C.S.; validation, C.S., L.M. and D.G.; formal analysis, L.M.; investigation, J.H.; resources, L.H.; data curation, C.S.; writing-original draft preparation, C.S.; writing-review and editing, L.M.; visualization, L.M.; supervision, Y.C., D.G.; project administration, D.G.; funding acquisition, D.G.

Funding: This research was funded by the National Natural Science founding of China, grant number 41501568. Supported by Open Fund of Key Laboratory of Geospatial Technology for the Middle and Lower Yellow River Regions (Henan University), Ministry of Education (Grant No. GTYR201803).

Acknowledgments: We thank H. Cao from South China Botanical Garden, Chinese Academy of Sciences for comment on this manuscript. We would like to thank Joshua Daskin at Yale University for his assistance with English language and grammatical editing.

Conflicts of Interest: The authors declare no conflict of interest.

\section{References}

1. Stockmann, U.; Padarian, J.; McBratney, A.; Minasny, B.; De Brogniez, D.; Montanarella, L.; Hong, S.Y.; Rawlins, B.G.; Field, D.J. Global soil organic carbon assessment. Glob. Food Secur. 2015, 6, 9-16. [CrossRef]

2. Ye, L.; Tan, W.; Fang, L.; Ji, L.; Deng, H. Spatial analysis of soil aggregate stability in a small catchment of the Loess Plateau, China: II. Spatial prediction. Soil Tillage Res. 2019, 192, 1-11. [CrossRef]

3. Gunina, A.; Kuzyakov, Y. Pathways of litter C by formation of aggregates and SOM density fractions: Implications from 13C natural abundance. Soil Biol. Biochem. 2014, 71, 95-104. [CrossRef]

4. Yavitt, J.B.; Fahey, T.J.; Sherman, R.E.; Groffman, P.M. Lumbricid earthworm effects on incorporation of root and leaf litter into aggregates in a forest soil, New York State. Biogeochemistry 2015, 125, 261-273. [CrossRef]

5. Xu, L.; Shi, Y.; Fang, H.; Zhou, G.; Xu, X.; Zhou, Y.; Tao, J.; Ji, B.; Xu, J.; Li, C.; et al. Vegetation carbon stocks driven by canopy density and forest age in subtropical forest ecosystems. Sci. Total Environ. 2018, 631, 619-626. [CrossRef] [PubMed]

6. Riitters, K.; Jones, K.B.; Wade, T.G.; Wickham, J.D. Distribution and Causes of Global Forest Fragmentation. Conserv. Ecol. 2003, 7, 1850-1851.

7. Miller-Rushing, A.J.; Primack, R.B.; Devictor, V.; Corlett, R.T.; Cumming, G.S.; Loyola, R.; Maas, B.; Pejchar, L. How does habitat fragmentation affect biodiversity? A controversial question at the core of conservation biology. Biol. Conserv. 2019, 232, 271-273. [CrossRef]

8. Song, W.; Lin, G.; Cao, H.; Ma, L. Beta diversity pattern and its driving forces of fengshui woods in South China. Bangladesh J. Bot. 2016, 45, 905-910.

9. Villard, M.-A.; Metzger, J.P.; Saura, S. REVIEW: Beyond the fragmentation debate: A conceptual model to predict when habitat configuration really matters. J. Appl. Ecol. 2014, 51, 309-318. [CrossRef]

10. Magnago, L.F.S.; Rocha, M.F.; Meyer, L.; Martins, S.V.; Meira-Neto, J.A.A. Microclimatic conditions at forest edges have significant impacts on vegetation structure in large Atlantic forest fragments. Biodivers. Conserv. 2015, 24, 2305-2318. [CrossRef]

11. Ma, L.; Shen, C.; Lou, D.; Fu, S.; Guan, D. Patterns of ecosystem carbon density in edge-affected fengshui forests. Ecol. Eng. 2017, 107, 216-223. [CrossRef]

12. Barros, H.S.; Fearnside, P.M. Soil carbon stock changes due to edge effects in central Amazon forest fragments. For. Ecol. Manag. 2016, 379, 30-36. [CrossRef] 
13. Baker, T.P.; Jordan, G.J.; Baker, S.C. Microclimatic edge effects in a recently harvested forest: Do remnant forest patches create the same impact as large forest areas? For. Ecol. Manag. 2016, 365, 128-136. [CrossRef]

14. Pütz, S.; Groeneveld, J.; Henle, K.; Knogge, C.; Martensen, A.C.; Metz, M.; Metzger, J.P.; Ribeiro, M.C.; De Paula, M.D.; Huth, A. Long-term carbon loss in fragmented Neotropical forests. Nat. Commun. 2014, 5, 5037. [CrossRef]

15. Malmivaara-Lämsä, M.; Hamberg, L.; Haapamäki, E.; Liski, J.; Kotze, D.J.; Lehvävirta, S.; Fritze, H. Edge effects and trampling in boreal urban forest fragments-Impacts on the soil microbial community. Soil Biol. Biochem. 2008, 40, 1612-1621. [CrossRef]

16. Laurance, W.F.; Ferreira, L.V.; Merona, J.M.R.-D.; Laurance, S.G. Rain forest fragmentation and the dynamics of Amazonian tree communities. Ecology 1998, 79, 2032-2040. [CrossRef]

17. Laurance, W.F.; Camargo, J.L.; Luizao, R.C.C.; Laurance, S.G.W.; Pimm, S.L.; Bruna, E.M.; Stouffer, P.C.; Williamson, G.B.; Benitez, J.; Vasconcelos, H.; et al. The fate of Amazonian forest fragments: A 32-year investigation. Biol. Conserv. 2013, 144, 56-67. [CrossRef]

18. Ma, L.; Shen, C.; Lou, D.; Fu, S.; Guan, D. Ecosystem carbon storage in forest fragments of differing patch size. Sci. Rep. 2017, 7, 13173. [CrossRef]

19. Six, J.; Paustian, K. Aggregate-associated soil organic matter as an ecosystem property and a measurement tool. Soil Biol. Biochem. 2014, 68, 4-9. [CrossRef]

20. Denef, K.; Zotarelli, L.; Boddey, R.M.; Six, J. Microaggregate-associated carbon as a diagnostic fraction for management-induced changes in soil organic carbon in two Oxisols. Soil Biol. Biochem. 2007, 39, 1165-1172. [CrossRef]

21. Hontoria, C.; Gómez-Paccard, C.; Mariscal-Sancho, I.; Benito, M.; Pérez, J.; Espejo, R. Aggregate size distribution and associated organic $\mathrm{C}$ and $\mathrm{N}$ under different tillage systems and Ca-amendment in a degraded Ultisol. Soil Tillage Res. 2016, 160, 42-52. [CrossRef]

22. Jiang, Y.; Qian, H.; Wang, X.; Chen, L.; Liu, M.; Li, H.; Sun, B. Nematodes and microbial community affect the sizes and turnover rates of organic carbon pools in soil aggregates. Soil Biol. Biochem. 2018, 119, $22-31$. [CrossRef]

23. Lorenz, K.; Preston, C.M.; Krumrei, S.; Feger, K.-H. Decomposition of needle/leaf litter from Scots pine, black cherry, common oak and European beech at a conurbation forest site. Eur. J. For. Res. 2004, 123, 177-188. [CrossRef]

24. Hansson, K.; Helmisaari, H.-S.; Sah, S.P.; Lange, H. Fine root production and turnover of tree and understorey vegetation in Scots pine, silver birch and Norway spruce stands in SW Sweden. For. Ecol. Manag. 2013, 309, 58-65. [CrossRef]

25. Sun, T.; Dong, L.; Mao, Z.; Li, Y. Fine root dynamics of trees and understorey vegetation in a chronosequence of Betula platyphylla stands. For. Ecol. Manag. 2015, 346, 1-9. [CrossRef]

26. Matamala, R.; Gonzàlez-Meler, M.A.; Jastrow, J.D.; Norby, R.J.; Schlesinger, W.H. Impacts of Fine Root Turnover on Forest NPP and Soil C Sequestration Potential. Science 2003, 302, 1385-1387. [CrossRef]

27. Terzaghi, M.; Di Iorio, A.; Montagnoli, A.; Baesso, B.; Scippa, G.S.; Chiatante, D. Forest canopy reduction stimulates xylem production and lowers carbon concentration in fine roots of European beech. For. Ecol. Manag. 2016, 379, 81-90. [CrossRef]

28. Wang, H.; Liu, S.; Wang, J.; Shi, Z.; Lu, L.; Guo, W.; Jia, H.; Cai, D. Dynamics and speciation of organic carbon during decomposition of leaf litter and fine roots in four subtropical plantations of China. For. Ecol. Manag. 2013, 300, 43-52. [CrossRef]

29. Tamura, M.; Suseela, V.; Simpson, M.; Powell, B.; Tharayil, N. Plant litter chemistry alters the content and composition of organic carbon associated with soil mineral and aggregate fractions in invaded ecosystems. Glob. Chang. Biol. 2017, 23, 4002-4018. [CrossRef]

30. Del Giudice, R.; Lindo, Z. Short-term leaching dynamics of three peatland plant species reveals how shifts in plant communities may affect decomposition processes. Geoderma 2017, 285, 110-116. [CrossRef]

31. Yan, J.; Wang, L.; Hu, Y.; Tsang, Y.F.; Zhang, Y.; Wu, J.; Fu, X.; Sun, Y. Plant litter composition selects different soil microbial structures and in turn drives different litter decomposition pattern and soil carbon sequestration capability. Geoderma 2018, 319, 194-203. [CrossRef]

32. Ma, L.; Huang, M.; Shen, Y.; Cao, H.; Wu, L.; Ye, H.; Lin, G.; Wang, Z. Species diversity and community structure in forest fragments of Guangzhou, South China. J. Trop. For. Sci. 2015, 27, 148-157. 
33. Katayama, A.; Kho, L.K.; Makita, N.; Kume, T.; Matsumoto, K.; Ohashi, M. Estimating Fine Root Production from Ingrowth Cores and Decomposed Roots in a Bornean Tropical Rainforest. Forests 2019, 10, 36. [CrossRef]

34. Liao, Y.; McCormack, M.L.; Fan, H.; Wang, H.; Wu, J.; Tu, J.; Liu, W.; Guo, D. Relation of fine root distribution to soil C in a Cunninghamia lanceolata plantation in subtropical China. Plant Soil 2014, 381, 225-234. [CrossRef]

35. R Team. R: A Language and Environmental for Statistical Computing; R Foundation for Statistical Computing: Vienna, Austria, 2013.

36. Li, W.; Zheng, Z.C.; Li, T.X.; Liu, M.Y. Distribution characteristics of soil aggregates and its organic carbon in different tea plantation age. Acta Ecol. Sin. 2014, 34, 6326-6336.

37. Zhao, D.; Xu, M.; Liu, G.; Ma, L.; Zhang, S.; Xiao, T.; Peng, G. Effect of vegetation type on microstructure of soil aggregates on the Loess Plateau, China. Agric. Ecosyst. Environ. 2017, 242, 1-8. [CrossRef]

38. Qiu, L.; Wei, X.; Gao, J.; Zhang, X. Dynamics of soil aggregate-associated organic carbon along an afforestation chronosequence. Plant Soil 2015, 391, 237-251. [CrossRef]

39. Six, J.; Elliott, E.; Paustian, K. Soil macroaggregate turnover and microaggregate formation: A mechanism for $C$ sequestration under no-tillage agriculture. Soil Biol. Biochem. 2000, 32, 2099-2103. [CrossRef]

40. Six, J.; Bossuyt, H.; DeGryze, S.; Denef, K. A history of research on the link between (micro) aggregates, soil biota, and soil organic matter dynamics. Soil Tillage Res. 2004, 79, 7-31. [CrossRef]

41. Arai, M.; Miura, T.; Tsuzura, H.; Minamiya, Y.; Kaneko, N. Two-year responses of earthworm abundance, soil aggregates, and soil carbon to no-tillage and fertilization. Geoderma 2018, 332, 135-141. [CrossRef]

42. Pulleman, M.; Six, J.; Uyl, A.; Marinissen, J.; Jongmans, A. Earthworms and management affect organic matter incorporation and microaggregate formation in agricultural soils. Appl. Soil Ecol. 2005, 29, 1-15. [CrossRef]

43. Blazejewski, G.A.; Stolt, M.H.; Gold, A.J.; Groffman, P.M. Macro- and Micromorphology of Subsurface Carbon in Riparian Zone Soils. Soil Sci. Soc. Am. J. 2005, 69, 1320-1329. [CrossRef]

44. Liusui, Y.; Zhu, X.; Li, D.; Yan, C.; Sun, T.; Jia, H.; Zhao, X. Soil aggregate and intra-aggregate carbon fractions associated with vegetation succession in an alpine wetland of Northwest China. Catena 2019, 181, 104107. [CrossRef]

45. Six, J.; Elliott, E.T.; Paustian, K. Aggregate and Soil Organic Matter Dynamics under Conventional and No-Tillage Systems. Soil Sci. Soc. Am. J. 1999, 63, 1350. [CrossRef]

46. Gentile, R.; Vanlauwe, B.; Six, J. Litter quality impacts short- but not long-term soil carbon dynamics in soil aggregate fractions. Ecol. Appl. 2011, 21, 695-703. [CrossRef]

47. Zhong, X.-L.; Li, J.-T.; Li, X.-J.; Ye, Y.-C.; Liu, S.-S.; Hallett, P.D.; Ogden, M.R.; Naveed, M. Physical protection by soil aggregates stabilizes soil organic carbon under simulated $\mathrm{N}$ deposition in a subtropical forest of China. Geoderma 2017, 285, 323-332. [CrossRef]

48. Bani, A.; Pioli, S.; Ventura, M.; Panzacchi, P.; Borruso, L.; Tognetti, R.; Tonon, G.; Brusetti, L. The role of microbial community in the decomposition of leaf litter and deadwood. Appl. Soil Ecol. 2018, 126, 75-84. [CrossRef]

49. Reinmann, A.B.; Hutyra, L.R. Edge effects enhance carbon uptake and its vulnerability to climate change in temperate broadleaf forests. Proc. Natl. Acad. Sci. USA 2017, 114, 107-112. [CrossRef]

50. Venugopal, P.; Junninen, K.; Linnakoski, R.; Edman, M.; Kouki, J. Climate and wood quality have decayer-specific effects on fungal wood decomposition. For. Ecol. Manag. 2016, 360, 341-351. [CrossRef]

51. Otsing, E.; Barantal, S.; Anslan, S.; Koricheva, J.; Tedersoo, L. Litter species richness and composition effects on fungal richness and community structure in decomposing foliar and root litter. Soil Biol. Biochem. 2018, 125, 328-339. [CrossRef]

52. Caplan, J.S.; Meiners, S.J.; Flores-Moreno, H.; McCormack, M.L. Fine-root traits are linked to species dynamics in a successional plant community. Ecology 2019, 100, e02588. [CrossRef] [PubMed]

53. Ladegaard-Pedersen, P.; Elberling, B.; Vesterdal, L. Soil carbon stocks, mineralization rates, and $\mathrm{CO}_{2}$ effluxes under 10 tree species on contrasting soil types. Can. J. For. Res. 2005, 35, 1277-1284. [CrossRef]

54. Finér, L.; Ohashi, M.; Noguchi, K.; Hirano, Y. Factors causing variation in fine root biomass in forest ecosystems. For. Ecol. Manag. 2011, 261, 265-277. [CrossRef]

55. Sun, Z.; Liu, X.; Schmid, B.; Bruelheide, H.; Bu, W.; Ma, K. Positive effects of tree species richness on fine-root production in a subtropical forest in SE-China. J. Plant Ecol. 2017, 10, 146-157. [CrossRef] 
56. Finér, L.; Domisch, T.; Dawud, S.M.; Raulund-Rasmussen, K.; Vesterdal, L.; Bouriaud, O.; Bruelheide, H.; Jaroszewicz, B.; Selvi, F.; Valladares, F. Conifer proportion explains fine root biomass more than tree species diversity and site factors in major European forest types. For. Ecol. Manag. 2017, 406, 330-350. [CrossRef]

57. Wurzburger, N.; Wright, S.J. Fine-root responses to fertilization reveal multiple nutrient limitation in a lowland tropical forest. Ecology 2015, 96, 2137-2146. [CrossRef]

58. Valverde-Barrantes, O.J.; Smemo, K.A.; Feinstein, L.M.; Kershner, M.W.; Blackwood, C.B. Aggregated and complementary: Symmetric proliferation, overyielding, and mass effects explain fine-root biomass in soil patches in a diverse temperate deciduous forest landscape. New Phytol. 2015, 205, 731-742. [CrossRef]

(C) 2019 by the authors. Licensee MDPI, Basel, Switzerland. This article is an open access article distributed under the terms and conditions of the Creative Commons Attribution (CC BY) license (http://creativecommons.org/licenses/by/4.0/). 